\title{
Regionalism and marine environmental protection: the case of offshore energy production
}

Nikolaos Giannopoulos, Postdoctoral Research Fellow at the Centre for Water, Oceans and Sustainability Law (UCWOSL) of Utrecht University, Senior Research Associate at the Netherlands Institute for Law of the Sea (NILOS), n.giannopoulos@uu.nl

\section{Introduction}

Despite the progress achieved in the international environmental regulation of offshore energy production activities, there are still significant normative gaps in terms of globally applicable environmental standards. ${ }^{1}$ Global agreements do not offer concrete environmental standards specifically applicable to offshore energy production activities, but they create normatively modest obligations, which allow States wide discretion in their implementation. ${ }^{2}$ By contrast, most of the specific environmental rules and standards concerning energy activities at sea have been developed at the regional level. ${ }^{3}$ Regional instruments are not considered here as a self-standing alternative in relation to the global legal framework, but as implementing, supplementing and complementing that framework. ${ }^{4}$ Indeed, UNCLOS accommodates and, in certain instances, encourages the development of regional agreements for the protection of the marine environment. ${ }^{5}$ In that context, it is posited that regional marine environmental protection instruments shape the implementation of the duty to protect and preserve the marine environment in relation to offshore energy activities, by adding normative content to it. Equally importantly, regional arrangements entail institutional mechanisms, which allow them to regularly review and adapt those norms to the changing region-specific needs and interests.

Nonetheless, the protection of the marine environment from offshore energy activities is by no means an exclusively regional issue. The offshore energy industry is operating on a global scale, and many regions around the world face the ensuing environmental challenges. That being said, not all energy-producing marine regions are subject to normatively specific rules and standards to regulate these activities in an environmentally sustainable manner. ${ }^{6}$ Theoretically, the absence of such standards might have significant environmental repercussions. Given the interconnectedness of seas and oceans, the success of a regional agreement in achieving its environmental objectives depends considerably on the consistent efforts in the other areas of the world

\footnotetext{
${ }^{1}$ On the concept of normative gaps, see also D French, and L Kotze (2019) 'Towards a Global Pact for the Environment: International Environmental Law's Factual, Technical and (Unmentionable) Normative Gaps', Review of European, Comparative and International Environmental Law, 28-29.

${ }^{2}$ N Giannopoulos (2019) 'Global Environmental Regulation of Offshore Energy Production: Searching for Legal Standards in Ocean Governance', Review of European, Comparative and International Environmental Law, 289-303.

${ }^{3}$ C Redgwell (2014) 'Mind the Gap in the GAIRS: The Role of Other Instruments in LOSC Regime Implementation in the Offshore Energy Sector', International Journal of Marine and Coastal Law, 611. ${ }^{4}$ D Alheritiere (1982) Marine Pollution control regulation: Regional Approaches, Marine Policy, 170.

${ }^{5}$ For instance, articles 123, 197, 208(3) UNCLOS.

${ }^{6}$ Redgwell (2014) supra n. 3, 603.
} 
to equally protect the marine environment. ${ }^{7}$ On that account, it is essential to assess the legal relevance of these region-specific rules and standards for other marine areas, for which there are no specific rules on the environmental regulation of offshore energy production activities.

The aim of this contribution is two-fold: it purports to examine the role of regional agreements for the regulation of offshore energy production both within and beyond their geographical scope of application. The paper proceeds by first identifying what is meant by regionalism in the context of marine environmental protection and how regionalism is accommodated as a framework of environmental cooperation under UNCLOS. Section 2 examines the role of regional agreements in specifying and updating the standard of diligence that States must exercise in the respective marine areas. To that end, it touches upon examples of relevant normative and institutional developments in four regions, namely the Mediterranean Sea, the Baltic Sea, the NorthEast Atlantic and the Arctic Ocean. Drawing on these developments, it extrapolates the significant contribution of the regional agreements in developing future-proof and inclusive regulation of offshore energy production activities. Section 3 then discusses the potential "extraterritorial" legal relevance of regional rules and standards, and, in particular, their role in informing the interpretation and implementation of UNCLOS.

\section{Regionalism in the law of the sea and marine environmental protection}

Arguably, a global approach to the law of the sea "blends harmoniously with the principle of the freedom of the seas" because it is linked to the oceans' historical use as a medium for international shipping. ${ }^{8}$ Nonetheless, a regional approach to the making and implementation of the law of the sea focuses on overcoming challenges created by the use of ocean space for localised economic purposes, such as the exploitation of offshore energy resources. ${ }^{9}$ Although "the law of the sea is inherently global", ${ }^{10}$ not every environmental problem needs to be resolved at the global level, nor only at the global level, insofar as global considerations are not overriding. ${ }^{11}$ The environmental risks posed by offshore energy production offer a characteristic example in that respect.

\subsection{The concept of regionalism in the context of marine environmental protection}

Before discussing the value of regionalism for the protection of the marine environment, it is important first to comprehend its meaning and operation. The terms region and regional consist of concepts to define the physical and intellectual limits of a subject matter in the law-making or implementation process. ${ }^{12}$ In the context of the law of the sea, regionalism has been perceived as referring either to regions of the

\footnotetext{
7 A Zervaki (2016) 'The Legalization of Maritime Spatial Planning in the European Union and Its Implications for Maritime Governance', Ocean Yearbook, 40-41.

${ }^{8}$ R-J Dupuy, and D Vignes, A Handbook on the New Law of the Sea (Martinus Nijhoff, 1991) 44-45.

${ }^{9}$ C Brown (1998) 'International Environmental Law in the Regulation of Offshore Installations and Seabed Activities: The Case for a South Pacific Regional Protocol', Australian Mining \& Petroleum Law Journal, 126.

${ }^{10}$ A Boyle, 'Globalism and Regionalism in the Protection of the Marine Environment' in D Vidas (ed) Protecting the Polar Marine Environment: Law and Policy for Pollution Prevention (CUP, 2000) 20.

${ }^{11}$ Alheritiere (1982) supra n. 4, 172.

${ }^{12}$ A Chircop (1989) 'Participation in Marine Regionalism: An Appraisal in a Mediterranean Context', Ocean Yearbook, 404.
} 
marine environment or regional arrangements (agreements, other instruments and institutions) that are related to "the management of oceans and their resources at the regional level through mechanisms designed to implement various types of cooperative activities among States, particularly those in a contiguous geographic area". ${ }^{13}$ In the latter case, regionalism refers to an approach for the management of a marine area defined by its geographic or physical characteristics, such as its enclosed or semienclosed character, concentrating on relevant patterns of its use through an agreement to cooperate of an interested group of States.

Despite the importance attached to regional arrangements for marine environmental protection under UNCLOS, neither the Convention nor any other relevant international instrument clarifies what a marine region is. ${ }^{14}$ On the contrary, it appears that the concepts of region and regional are not used symmetrically under the Convention. ${ }^{15}$ Except for the slightly loose description of enclosed and semi-enclosed seas under its article $122,{ }^{16}$ UNCLOS does not contain any prescriptive definition of a marine region, nor does it contain a list of enclosed and semi-enclosed seas. Furthermore, one cannot deduce a clear description of a marine region from the way in which the UNEP Regional Seas Programme (RSP) treats the concept. For instance, the RSP has attributed the qualification of regional seas to the "enclosed or semi-enclosed seas, as well as marine and coastal areas of regions with well-defined common problems" ${ }^{17}$ In that respect, even regions that are regulated by regional sea agreements under the auspices of the RSP differ widely: some are oceanic, some are semi-enclosed, and others are based on island groupings. Therefore, the term region can cover marine areas of considerably different sizes. ${ }^{18}$

Based on the characteristics of various regions regulated under regional sea agreements, a marine region could arguably be defined as a maritime area that is geographically distinct and in which a group of States share a sense of solidarity, in the sense that they face common challenges and have similar interests to protect in collectively regulating ocean activities. ${ }^{19}$ More specifically, for marine environmental protection, a marine region is such a geographically distinct maritime area where the environmental challenges call for the adoption of specific rules but also within which

\footnotetext{
${ }^{13}$ B Boczek (1984) 'Global and Regional Approaches to the Protection and Preservation of the Marine Environment', Case Western Reserve Journal of International Law, 39, L Alexander (1994) 'New Trends in Marine Regionalism', Ocean Yearbook, 1.

${ }^{14}$ The 1958 Geneva Conventions on the Law of the Sea referred to the word region only twice, see article 4(4) of the Convention on the Territorial Sea and the Contiguous Zone and article 12(2) of the Convention on the High Seas.

${ }^{15}$ Chircop (1989) supra $\mathrm{n} .12,405-406$.

${ }^{16}$ B Vukas, 'The Mediterranean: An Enclosed or Semi-Enclosed Sea?' in B Vukas (ed) The Legal Regime of Enclosed or Semi-Enclosed Seas: The Particular Case of the Mediterranean (Birotehnika, 1988) 40.

17 A Vallega (2002) 'The Regional Approach to the Ocean, the Ocean Regions, and Ocean Regionalisation - a Post Modern Dilemma', Ocean \& Coastal Management, 743-744.

18 E Molenaar, A Oude Elferink, D Rothwell (eds) The Law of the Sea and the Polar Regions: Interactions between Global and Regional Regimes (Brill, 2013) 5.

${ }^{19}$ See article VIII of the 1972 Convention on the Prevention of marine Pollution by Dumping of Wastes and other Matter, according to which, States with common interests in protecting the marine environment in a given geographical area "shall endeavour, taking into account characteristic regional features, to enter into regional agreements consistent with this Convention for the prevention of pollution, especially by dumping".
} 
the development of coastal States can benefit from international cooperation. ${ }^{20}$ This connotation of the marine region has been characterised as an "institutional", "operational" or "functional" area: ${ }^{21}$ a site for which one or more international arrangements are in effect to tackle specific marine environmental challenges. Therefore, a prescriptive definition of the term region does not seem to be necessary, since "any kind of co-operation developed by States in any given part of the ocean is regional", regardless of whether the specific maritime area has features justifying its qualification as a region. ${ }^{22}$

1.2. Regionalism as a framework of cooperation for marine environmental protection under UNCLOS

UNCLOS contains numerous references, both explicit and implicit, to the need for regional cooperation, regional rules and programmes. For instance, regional cooperation is required under the provisions for the management of living resources, ${ }^{23}$ the development and transfer of marine technology, ${ }^{24}$ the management of enclosed or semi-enclosed seas ${ }^{25}$ and the protection and preservation of the marine environment. Most of these provisions require the formulation of specific (regional) agreements for their implementation. ${ }^{26}$ These references to regional rules and standards under Part XII of UNCLOS also consist of a pragmatic recognition of the pre-existing State practice in adopting regional agreements.

Article 197 of UNCLOS is perhaps the strongest endorsement found in the Convention of the utility of regional instruments in addressing local particularities, ${ }^{27}$ such as "coastal geography, the physical characteristics of an ocean area, the distribution of specific species or valuable ecosystems and the pathways along which marine pollutants spread". ${ }^{28}$ The duty to cooperate for the furtherance of environmental rules, standards and recommended practices and procedures is also an acknowledgement that Part XII of UNCLOS was not intended to provide specific environmental standards for the regulation of all offshore activities. Therefore, regional marine environmental agreements may constitute a means of implementation of that obligation to cooperate in the development of regional rules under UNCLOS, provided that they are "concluded in furtherance of the general principles and objectives of the Convention". ${ }^{29}$ For instance, in the Mox Plant Case, the UK argued that it had complied with its duty under article 197 of UNCLOS "inter alia, through its ratification of the

\footnotetext{
${ }^{20}$ Vallega (2002) supra n. 17, 743.

${ }^{21}$ Dupuy and Vignes, supra n. 8, 54.

${ }^{22}$ A Vallega (1994) 'The Regional Scale of Ocean Management and Marine Region Building', Ocean and Coastal Management, 22-23.

${ }^{23}$ Articles 61-64, 66, 69-70 and 118-119 of UNCLOS.

${ }^{24}$ Articles 268, 270, 272-273, 275 and 277 of UNCLOS.

${ }^{25}$ Articles $122-123$ of UNCLOS.

${ }^{26}$ B Baker (2013) 'The Developing Regional Regime for the Marine Arctic' in Oude Elferink, Molenaar, Rothwell (eds) supra n. 18, 48.

27 J Morgan (1994) 'The Marine Region', Ocean and Coastal Management, 68. See also article 207(4) of UNCLOS.

${ }^{28}$ Molenaar, Oude Elferink and Rothwell (2013) supra n. 18, 5.

${ }^{29}$ Article 237(1) of UNCLOS.
} 

and Euratom". ${ }^{30}$

Noticeably, article 197 of UNCLOS appears to qualify the duty to adopt regional rules and standards using the phrase "as appropriate", without explaining when the regional approach is appropriate to tackle environmental threats. Seemingly, the Convention does not intend to prioritise the adoption of global rules and standards, but, instead, allows States to decide whether cooperation for the adoption of rules at the regional level is more suitable or feasible to deal with particular challenges. However, the Convention shows a preference for the most appropriate level of cooperation in respect of specific sources of pollution. ${ }^{31}$ An example of a situation where UNCLOS indicates that it is more appropriate to cooperate on the regional level for the formulation of environmental rules and standards is in respect of enclosed or semienclosed sea areas. ${ }^{32}$ The preference for special regional rules in the case of enclosed or semi-enclosed seas seems to be justified by their unique characteristics such as the complexity of navigation due to poor connection with other seas and the high risk from all sources of pollution due to their small size and the difficulty in dispersing pollutants in adjacent seas. ${ }^{33}$

Article 123 of UNCLOS directs States bordering enclosed or semi-enclosed seas to cooperate, directly or through an appropriate regional organisation, ${ }^{34}$ when exercising their rights and complying with their obligations under the Convention. Notably, the provision dictates that States "shall endeavour to coordinate the implementation of their rights and duties with respect to the protection and preservation of the marine environment". ${ }^{35}$ Vukas has argued that the provision should be interpreted as stimulating "the cooperation of States and international organisations in respect of the use and protection of enclosed or semi-enclosed seas as well as to the adoption of regional and sub-regional rules concerning particular seas". ${ }^{36}$ Contrary to article 197, article 123 of UNCLOS is "couched in the language of exhortation"37 ("shall endeavour") to avoid imposing an unconditional duty to participate in a distinctive regional agreement upon coastal States which, for various reasons, are not willing to create or join such a regime. However, the fact that the provision guides States to "coordinate the implementation of their rights and duties" could be read as an indication that it was intended to create a legal obligation of cooperation in such marine

\footnotetext{
${ }^{30}$ ITLOS, MOX Plant Case (Ireland v. United Kingdom), Provisional Measures, Written Response of the United Kingdom, 15 November 2001, para. 13.

${ }^{31}$ Molenaar, Oude Elferink, and Rothwell (2013) supra n. 18, 4.

32 PCA, South China Sea Arbitration (Republic of the Philippines v People's Republic of China) Award of 12 July 2016, para 946, where the tribunal emphasized the importance of regional cooperation in the case of semi-enclosed seas.

${ }^{33}$ B Vukas, 'United Nations Convention on the Law of the Sea and the Polar Marine Environment', in D Vidas (2000) supra n. 10, 40.

${ }^{34}$ Regional coordination of activities to protect the marine environment had already been set up in certain marine areas under the auspices of the UNEP, see M Nordquist, N Grandy, S Nandan, and S Rosenne (eds) United National Convention on the Law of the Sea 1982: A Commentary, Volume III (Brill, 1995) 367-368.

${ }^{35}$ Article 123(b) of UNCLOS

${ }^{36}$ B Vukas, 'The Mediterranean: An Enclosed or Semi-Enclosed Sea?' in B Vukas (ed) The Legal Regime of Enclosed or Semi-Enclosed Seas: The Particular Case of the Mediterranean (Birotehnika, 1988) 64.

${ }^{37}$ Nordquist, Grandy, Nandan and Rosenne (1995) supra n. 34, 366.
} 
areas. ${ }^{38}$ According to the tribunal in the Chagos Marine Protected Area arbitration, such an obligation imposes a duty to use the best efforts to achieve the harmonisation of environmental policies at the regional level. ${ }^{39}$

It has also been posited that the provision introduced a sui generis obligation for cooperation, which would be breached if a State systematically rejected any negotiations for the protection and preservation of the marine environment. ${ }^{40}$ Furthermore, it has been proposed that the duty to cooperate under article 123 is linked to article 197 of UNCLOS and must be considered as an augmented obligation for States bordering enclosed and semi-enclosed seas. In that sense, in the Mox Plant case, Ireland argued that there was a "heightened" obligation for States bordering a semienclosed sea to cooperate under article 123 additional to the one reflected in article 197 of the Convention. ${ }^{41}$ According to Ireland's position, interpreting article 123 of UNCLOS as imposing an enhanced obligation of cooperation is justified on practical reasons. $^{42}$ In the author's view, though, the argument in favour of an enhanced obligation of cooperation under article 123 seems to suggest its interpretation de lege ferenda. On another occasion, in the Land Reclamation case, Malaysia asked for provisional measures, alleging that Singapore had breached the obligation under article 123 of UNCLOS due to its failure to cooperate. ${ }^{43}$ While in both cases ITLOS rejected the provisional measures requested by Ireland and Malaysia respectively, it ordered the parties to cooperate in the exchange of information, to monitor the risks of the contested activities and to consult before devising all appropriate measures to protect the marine environment. $^{44}$

In the South China Sea Arbitration, the Philippines claimed that China had breached its duty of cooperation under articles 197 and 123 of UNCLOS "the latter of which takes into account the characteristic regional features which would include the fundamental biological and ecological importance and fragile nature of the coral reef ecosystem of the South China Sea". ${ }^{45}$ The arbitral tribunal unequivocally referred to article 123 as the relevant provision regarding regional environmental cooperation under UNCLOS without entering into details as to its normative content. ${ }^{46}$ In that regard, the tribunal implied that article 123 of UNCLOS creates an obligation for States bordering a semi-enclosed sea to coordinate the implementation of their duties for the protection of the marine environment. ${ }^{47}$ In the tribunal's view, the provision imposes

\footnotetext{
${ }^{38}$ C Linebaugh (2014) 'Joint Development in a Semi-Enclosed Sea: China's Duty to Cooperate in Developing the Natural Resources of the South China Sea', Columbia Journal of Transnational Law, 560.

${ }^{39}$ PCA, Chagos Marine Protected Area Arbitration (Mauritius v United Kingdom), Award of 18 March 2015, para 539.

${ }^{40}$ Vukas (2000) supra n. 33, 42.

${ }^{41}$ Request for Provisional Measures and Statement of the Case submitted on behalf of Ireland (Ireland $v$ United Kingdom), para 58.

${ }^{42}$ Ibid, paras 59-60

${ }^{43}$ ITLOS, Malaysia v Singapore Land Reclamation, Request for Provisional Measures, para 18.

${ }^{44}$ MOX Plant Case, para 89, Land Reclamation Case, para 106.

${ }^{45}$ South China Sea, para 910(e).

${ }^{46}$ Ibid, para 946.

${ }^{47}$ Ibid, para 986.
} 
an obligation of conduct, ${ }^{48}$ which at least entails an obligation to consult with the neighbouring States about measures of marine environmental protection. ${ }^{49}$ In light of the above, it could be deduced that article 123, read in combination with article 197 of UNCLOS, creates an obligation of conduct of States bordering enclosed or semienclosed seas to endeavour to cooperate in good faith in the development of further rules and standards on marine environmental protection. ${ }^{50}$ The two articles enjoy a "symbiotic legal relationship", ${ }^{1}$ where article 123 plays the implementing function of the duty to cooperate in the context of enclosed and semi-enclosed seas. Relevantly, regional sea agreements applying to enclosed and semi-enclosed seas consist of the primary mechanism in the implementation of articles 197 and 123 of UNCLOS.

\section{Regionalism and offshore energy production: enhancing the duty to protect and preserve the marine environment}

With regard to the environmental regulation of offshore energy activities, regional agreements have been operationalized as a means of not only implementing but also giving more concrete content to the normatively vague rules of UNCLOS. This section draws on normative and institutional developments under the OSPAR, ${ }^{52} \mathrm{Helsinki}^{53}$ and Barcelona Conventions, ${ }^{54}$ as well as various instruments adopted in the context of the Arctic Council, in light of the fact that States bordering the respective regions have developed specific rules regarding offshore energy activities. The examined regional instruments do not merely reiterate the general duties in relation to the protection and preservation of the marine environment under the Convention; they go further than that by specifying and continuously updating their normative contours to address local needs, taking into account characteristic regional features.

2.1. Adding normative content to the environmental duties concerning offshore energy activities

Regardless of the differences between regional arrangements, various reasons highlight the advantages of regional cooperation for marine environmental protection. ${ }^{55}$ In many instances, regional agreements contain more robust international environmental obligations concerning a specific sea area than the corresponding global rules. ${ }^{56}$ The examined second-generation regional sea agreements have given legally binding force to common environmental principles and approaches, such as the

\footnotetext{
${ }^{48}$ Grbec (2014) Extension of Coastal State Jurisdiction in Enclosed and Semi-Enclosed Seas: A Mediterranean and Adriatic Perspective (Routledge, 2014) 38.

${ }^{49}$ South China Sea, para 986.

${ }^{50}$ C Whomerley (2016) 'Regional Cooperation in the North Sea under Part IX of the Law of the Sea Convention', The International Journal of Marine and Coastal Law, 344.

${ }^{51} \mathrm{~N}$ Oral, Regional Co-operation and Protection of the Marine Environment Under International Law (Brill, 2013) 43.

${ }^{52}$ Convention for the Protection of the Marine Environment of the North-East Atlantic ILM 1069 (1993).

${ }^{53}$ Convention on the Protection of the Marine Environment of the Baltic Sea Area (Helsinki).

${ }^{54}$ Convention for the Protection of Marine Environment and the Coastal Region of the Mediterranean.

${ }^{55}$ C Okidi, 'Protection of the Marine Environment Through Regional Arrangements', in A H A Soons (ed) Implementation of the Law of the Sea Convention Through International Institutions (Law of the Sea Institute, 1990) 477.

${ }^{56} \mathrm{See}$, for instance, OSPAR, preambular paragraph 11.
} 
precautionary principle and the ecosystem-based approach, ${ }^{57}$ which until the Rio Conference in 1992, existed as merely non-binding recommendations. ${ }^{58}$ In particular, they require States to take measures beyond traditional pollution prevention, such as measures to restore degraded marine ecosystems, ${ }^{59}$ adopting a more holistic perspective in managing offshore activities. ${ }^{60}$ The duty of marine biodiversity conservation is significantly relevant to marine renewable energy production which, unlike traditional fossil fuel exploitation, does not always emit substances or energy, but may create other types of disturbances for marine ecosystems. For instance, the OSPAR Strategy on the Protection and Conservation of Ecosystems and Biological Diversity of the Maritime Area contains a suggested list of offshore energy activities, which the OSPAR Commission needs to assess for their likely potential adverse effect on marine ecosystems and species. ${ }^{61}$ These regional sea agreements and the Espoo Convention initially developed as regional - also add normative content to the requirements to conduct Environmental Impact Assessments (EIAs) and to continuously monitor offshore energy production operations, ${ }^{62}$ introducing new elements, such as the duty to conduct Strategic Environmental Assessments (SEAs) and to enable public participation. ${ }^{63}$

Importantly, the selected regional sea instruments also contain substantive environmental rules on offshore energy production activities. Concerning offshore oil and gas exploitation, a series of binding rules have been formulated, regarding both the prevention of operational pollution and the response to accidental pollution. ${ }^{64}$ However, there is increased emphasis on the development of regional rules for the preparedness and response to accidental oil pollution rather than the prevention of operational discharges. For instance, even in the context of the Arctic Council, there is a binding convention on response to accidental pollution while the rules relating to the prevention of operational pollution are included in non-binding guidelines. ${ }^{65}$ The EU Offshore Safety Directive offers another example of that focus on response to accidental

\footnotetext{
${ }^{57}$ See the Statement on the Ecosystem Approach to the Management of Human Activities (Joint Meeting of the Helsinki and OSPAR Commissions 2003), Annex 5, para 5.

${ }^{58}$ P Sands, J Peel, A Fabra, and R Mackenzie (eds) Principles of International Environmental Law (CUP, $4^{\text {th }}$ edition, 2018) 461.

${ }^{59}$ OSPAR, Annex V, article 1, Helsinki Convention, articles 3 and 15, Barcelona Convention, article 10.

${ }^{60} \mathrm{~T}$ Treves, 'Regional Approaches to the Protection of the Marine Environment' in M Nordquist, J Norton Moore, and S Mahmoudi (eds) The Stockholm Declaration and Law of the Marine Environment (Martinus Nijhoff, 2003) 145, M Gavouneli, 'New Forms of Cooperation in the Mediterranean System of Environmental Protection' in Nordquist, Norton Moor and Mahmoudi (2003) 224.

${ }^{61}$ This list includes the exploration for oil, gas, and solid minerals, the placement of structures for the exploitation of oil and gas, the construction and deployment of installations, structures, and the placement of cables and pipelines, see OSPAR Strategy on the Protection and Conservation of the Ecosystems and Biological Diversity of the Maritime Area, para 2.2.c. and 2.2.d.

621991 Espoo Convention on Environmental Impact Assessment in a Transboundary Context, Apendix I, para 15 and 22.

${ }^{63}$ See Protocol on Strategic Environmental Assessment to the Convention on Environmental Impact Assessment in a Transboundary Context, Kiev.

${ }^{64}$ OSPAR, Annex III, Helsinki Convention, Annexes VI and VII, Protocol for the Protection of the Mediterranean Sea Against Pollution Resulting from the Exploration and Exploitation of the Continental Shelf and Sea-bed.

65 Agreement on Cooperation on Marine Oil Pollution Preparedness and Response in the Arctic (MOSPA).
} 
pollution. ${ }^{66}$ It appears that the development of more elaborate treaty rules on prevention, preparedness and response to accidental pollution from offshore oil and gas exploitation is correlated with the fact that environmental cooperation has often been prompted by some form of environmental disaster. ${ }^{67}$ Perhaps the high costs and other vital State interests related to prevention measures are also crucial factors influencing the development of preventive obligations. ${ }^{68}$

Although regional approaches vary from more goal-oriented regulation in the case of the OSPAR Convention to more prescriptive models of management under the Helsinki and Barcelona Conventions, their shared objective is to set minimum environmental standards for offshore oil and gas activities in their respective regions. Notwithstanding the diverse context in which these regional rules have been formulated, there is strong convergence concerning norms regulating operational discharges from offshore oil and gas installations: all the examined instruments subject offshore oil and gas activities to prior authorisation and require States to apply dynamic standards of care, such as Best Available Techniques (BAT) and Best Environmental Practices (BEP). ${ }^{69}$ The use of dynamic environmental standards, which evolve as technology and science become more effective in preventing pollution, lies at the heart of the concept of due diligence. ${ }^{70}$ The requirement to apply BAT and BEP can limit the discretion of States concerning the implementation of their duty to restrict various discharges from the operation of offshore oil and gas installations depending on the level of risk and the increasing scientific awareness about it. ${ }^{71}$ Nonetheless, the vague definition of BET and BAT appears to allow considerable leeway to States to identify their content in the context of offshore activities, and, consequently, limit their legal implications. ${ }^{72}$ For instance, the effectiveness of technologies needs to be balanced with their costs, making economic feasibility an essential factor in determining which technology will qualify as being available. ${ }^{73}$

In furtherance of the duties under UNCLOS and building upon the relevant rules of the OPRC, regional sea agreements contain elaborate procedural safeguards to prevent, respond to and control pollution caused by offshore oil and gas accidents. Apart from the State-centred duties of notification, consultation and cooperation, they oblige both States and the operators of offshore oil and gas installations to formulate contingency

\footnotetext{
${ }^{66}$ Directive 2013/30/EU of 12 June 2003 on Safety of Offshore Oil and Gas Operations.

${ }^{67}$ Whomersley (2016) supra n. 50, 350 with reference to the House of Lords Report of Session 2014-15, 10 March 2015, Conclusions, para 18.

${ }^{68}$ Vidas (2000) supra n. 10, 93.

${ }^{69}$ OSPAR, Annex III, Article 2, Helsinki, Annex VI, Regulation 2, Offshore Protocol, article 10, see also Arctic Offshore Oil and Gas Guidelines, chapter 6.3

70 J Harrison (2017) Saving the Oceans through Law: The International Legal Framework for the Protection of the Marine Environment (OUP, 2017) 218.

${ }^{71}$ Y Tanaka (2006) 'Regulation of Land-Based Marine Pollution in International Law: A Comparative Analysis Between Global and Regional Frameworks', ZaöRV, 564.

${ }^{72}$ L de La Fayette (1999) 'The OSPAR Convention Comes into Force: Continuity and Progress', International Journal of Marine and Coastal Law, 256, J Hilf (1995) 'The Convention for the Protection of the Marine Environment of the North-East Atlantic- New Approaches to an Old Problem?', ZaöRV, 590 .

${ }^{73}$ E Hey, T Ijlstra, and A Nollkaemper (1993) '1992 Paris Convention for the Protection of the Marine Environment of the North-East Atlantic: A Critical Analysis', International Journal of Marine and Coastal Law, 16.
} 
plans and conduct exercises to ensure their capability in immediately responding to acute pollution. ${ }^{74}$ That way, they promote a co-regulatory approach, which can marry the benefits of public and private regulation. Under such an approach, the industry obtains an exceptional role, as it becomes responsible for the safety of its operations. Nonetheless, State supervision of the industry's normative developments and monitoring of their implementation are indispensable. ${ }^{75}$

When it comes to marine renewables, regional sea agreements offer generic protection against their potential environmental externalities. In particular, their general obligations apply as long as marine renewable energy generation cause, or might cause, pollution or involve activities which are directly regulated under these agreements. ${ }^{76}$ However, there have been some noteworthy secondary normative developments under their provisions on biodiversity conservation. ${ }^{77}$ Inter alia, these non-binding instruments guide States' compliance with their duties to conduct EIAs and SEAs, to continuously monitor the effects of offshore energy devices on marine ecosystems and protected species, to regulate emissions and other disturbances and even prohibit such activities in areas which are particularly crucial for the conservation of the ecological balance.

\subsection{The significant contribution of regional institutional frameworks}

As highlighted above, regional agreements usually create an institutional framework supporting the implementation of their rules and monitoring compliance by States. ${ }^{78}$ Although most regional marine environmental arrangements pursue common goals, they vary considerably concerning their institutional framework as well as their regulatory approaches. Some of these treaty bodies are mandated to develop the regional rules and standards, adopt interpretative guidelines and offer assistance to the parties concerning the implementation of the treaty.

Overall, the dynamism of cooperation and the potential for better implementation of the regional agreements appear to be higher so long as the institutional framework is robust. ${ }^{79}$ For instance, the OSPAR Commission has the power to adopt binding decisions and non-binding recommendations ${ }^{80}$ by unanimity and, when unanimity is not attainable, by a three-quarters majority vote. ${ }^{81}$ Carrying out its mandate, the OSPAR Commission has adopted a remarkable series of decisions, recommendations, and agreements to provide normative content to the obligations regarding offshore activities

\footnotetext{
${ }^{74}$ Helsinki Convention, Annex VII, Regulation 2, Offshore Protocol, Annex VII, MOSPA, article 6.

75 S Vinogradov (2013) 'The Impact of the Deepwater Horizon: The Evolving International Legal Regime for Offshore Accidental Pollution Prevention, Preparedness and Response', Ocean Development and International Law, 350.

${ }^{76}$ See, for instance, Helsinki Convention, article 2(7).

${ }^{77}$ See, for instance, OSPAR, Guidance on a Common Approach for Dealing with Applications for the Construction and Operation of Offshore Windfarms (2005), HELCOM Recommendation 34/E/1, Part of its 2013 Ministerial Declaration.

${ }^{78}$ There are though regions where the role played by institutions remain rather limited, P Birnie, A Boyle, and C Redgwell, International Law and the Environment (OUP, 3rd edition, 2009), 393.

${ }^{79}$ J Rochette and R Bille (2013) 'Bridging the Gap between Legal and Institutional Developments within Regional Seas Frameworks', International Journal of Marine and Coastal Law, 435.

${ }^{80}$ OSPAR, article $13(5)$.

${ }^{81}$ OSPAR, article $13(1)$.
} 
under Annex III and to guide States in their implementation. ${ }^{82}$ The adoption of these instruments is steered by the guiding principles and strategic directions laid down in the Offshore Oil and Gas Industry Strategy. ${ }^{83}$ In the context of the Baltic Sea, HELCOM is responsible for adopting recommendations that can substantiate the content of the provisions of the Helsinki Convention and its Annexes. ${ }^{84}$ The Response Working Group has developed the Manual on Co-operation in Response to Marine Pollution, ${ }^{85}$ whose rules elaborate on the obligations under Annex VII of the Helsinki Convention. ${ }^{86}$ HELCOM has also been instrumental in developing guidelines for the implementation of recommendations on accidental offshore oil pollution prevention and response ${ }^{87}$ However, unlike the OSPAR Commission, HELCOM has no authority to adopt binding decisions. ${ }^{88}$

In the Mediterranean, the Offshore Oil and Gas Group serves as a technical body for the exchange of best practices, knowledge, and experiences between its members to assist the parties in promulgating international rules, standards, and recommended practices and procedures according to article 23 of the Mediterranean Offshore Protocol. It is also assigned the periodic examination and review of the Offshore Action Plan. ${ }^{89}$ A particular feature of the Offshore Action Plan is that it encourages the participation of the industry as observers at the OFOG. It supports the engagement with existing cooperation initiatives with the offshore energy industry, ${ }^{90}$ to include these crucial stakeholders in the implementation of the Offshore Protocol in the Mediterranean. ${ }^{91}$ For instance, the International Association of Oil and Gas Producers has played an essential role in the drafting of the guidelines mentioned above by providing valuable feedback from their members and oil and gas operators.

Similarly, the Arctic Council has contributed to norm-shaping mostly through its specific working groups. ${ }^{92}$ For instance, PAME has been instrumental in the

\footnotetext{
${ }^{82}$ See OSPAR Strategy on Environmental Goals and Management Mechanisms for Offshore Activities, Reference Number 1999-12.

${ }^{83}$ OSPAR Agreement 2010-3, The North-East Atlantic Environment Strategy, Offshore Oil and Gas Industry, 19-24, see also previous OSPAR Strategy on Environmental Goals and Management Mechanisms for Offshore Activities, Agreement 1999-12.

${ }^{84}$ HELCOM Ministerial Declaration 2013, Copenhagen 3 October 2013, 1(R), 4(R) and 5(R), agreeing on the necessity to strengthen regional response systems.

${ }^{85}$ HELCOM Manual on Cooperation in Response to Marine Pollution, Vol 1.

${ }^{86}$ Helsinki Convention, Annex VII, Regulation 11.

${ }^{87}$ Guidelines for the implementation of HELCOM Recommendation 24/9 on ensuring adequate emergency capacity (HELCOM RESPONSE 2/2003, 13/1, Annex 3), Guidelines for applying HELCOM Recommendation 31/1 on development of national ability to respond to spillages of oil and other harmful substances (HELCOM RESPONSE 11/2009, 16/1/Rev.1, Annex 4).

${ }^{88}$ Helsinki Convention, article 20(1)(b).

${ }^{89}$ The tasks of the OFOG also include the preparation of guidelines on best practices, developing and applying common standards, keeping the technical content of the annexes under review, preparing draft measures to control the use of chemicals, oil and any other hazardous discharges from offshore oil and gas activities and assisting in defining targets for the implementation of the ecosystem approach, see Decision IG.21/8, Follow up Actions regarding the Offshore Action Plan, DOC UNEP/MED.IG.21/9, Annex II, 178.

${ }^{90}$ M Gavouneli, 'Oil Spill Response in the EU' in G Handl, and K Svendsen (eds) Managing the Risk of Offshore Oil and Gas Accidents: The International Legal Dimension (Edward Elgar, 2019) 132-133.

${ }^{91}$ Decision IG.21/8, Follow-up Actions regarding the Offshore Action Plan, DOC UNEP/MED.IG.21/9.

${ }^{92}$ R L Johnstone (2016) 'Environmental Governance through the Arctic Council: The Arctic Council as Initiator of Norms of International Environmental Law’, PCRC Working Paper No 1, 19
} 
development of Arctic-specific recommendations by drafting and regularly updating the Arctic Offshore Oil and Gas Guidelines. Under the auspices of the Arctic Council, States have also created the Emergency Prevention, Preparedness, and Response working group (EPPR) to develop guidelines on addressing oil spills in the Arctic. ${ }^{93}$ The EPPR has offered a forum for promoting region-specific environmental emergency response information among the Arctic States. For instance, it has drafted a series of maps identifying internationally important biological resources at risk from potential oil pollution in the Arctic and has pinpointed protected areas and species at risk in each area. ${ }^{94}$ Remarkably, the Arctic Council's instruments usually make recommendations that are not only addressed to domestic regulators but also the offshore industry. ${ }^{95}$ In that vein, the 2014 Arctic Offshore Oil and Gas Guidelines on System Safety Management and Safety Culture contain provisions on the cooperation among industry operators and regulators and incorporate the work of standard-setting organisations to involve the offshore energy industry. ${ }^{96}$ The 2014 Guidelines call on private industry and the regulators to work together to initiate, implement, monitor, and continuously improve standards and best practices for safety management systems and safety culture in Arctic offshore oil and gas operations. ${ }^{97}$ Scholars have positively received this acknowledgement and direct involvement of the offshore industry as an expression of "hybrid governance" of offshore oil and gas activities in the Arctic. ${ }^{98}$

Even though most of these "secondary" instruments are non-binding, they appear to be legally relevant in guiding the implementation of their respective agreements and, consequently, in shaping the standard of care required of States. With regard to decisions adopted by CoPs, the ILC draft conclusion 11(3) on subsequent agreements/practice states that they embody " $a$ subsequent agreement or subsequent practice under article 31, paragraph 4, in so far as it expresses agreement in substance between the parties regarding the interpretation of a treaty, regardless of the form and the procedure by which the decision was adopted, including by consensus". Even though that conclusion does not apply across the board to the output of all treaty bodies, these instruments can still qualify as "other" practice relevant for the interpretation of their respective agreements under article 32 of the VCLT. In that sense, they can contribute to the determination of the ordinary meaning of the respective treaty rules. ${ }^{99}$

In addition, their significance lies in their capacity to catalyse and influence domestic implementation measures or even to lead to the emergence of customary rules. The voluntary compliance of States with recommended actions under these non-binding instruments can result in the harmonisation of State practice in respect of the

\footnotetext{
${ }^{93}$ Ottawa Declaration, 19 September 1996, 1388.

${ }^{94} \mathrm{H}$ Mayrand (2015) 'Arctic Community of Practice and Offshore Oil and Gas Activities: Determining the Legal and Political Dimensions of the Obligation to Prevent, Reduce and Control Pollution”, McGill International Journal of Sustainable Development Law and Policy, 273.

${ }_{95}$ Arctic Ocean Review - Final Report, Chapter 9 Recommendations, para 17.

${ }^{96}$ Arctic Offshore Oil and Gas Guidelines on System Safety Management and Safety Culture, Section 4.2 .

${ }^{97}$ Ibid, 19

${ }^{98}$ H Osofsky, J Shadian, and S L Fechtelkotter (2016) ‘Arctic Energy Cooperation', University of California Davis Law Review, 1477.

${ }^{99} \mathrm{~S}$ Raffeiner (2016) 'Organ Practice in the Whaling Case: Consensus and Dissent between Subsequent Practice, Other Practice and a Duty to Give Due Regard', European Journal of International Law, 1056.
} 
implementation of the duty to protect the marine environment concerning offshore energy production. Such consistent and widespread practice can then, in principle, be considered as subsequent practice for the interpretation of UNCLOS. ${ }^{100}$ In addition, non-binding instruments can serve as benchmarks against which to evaluate the reasonableness of compliance measures adopted by States. In that sense, they can serve as recommended best practices, which are not the only way of implementing their duty to protect the marine environment in the context of offshore energy production, but if followed, conduct following their recommendations provides evidence that a State has acted diligently. ${ }^{101}$

Besides their significant normative output, regional institutional mechanisms can be more readily made available in case of an environmental emergency. ${ }^{102}$ For example, in the Mediterranean, the elaborate web of obligations is coordinated by the Regional Marine Pollution Emergency Response Centre for the Mediterranean Sea (REMPEC). The REMPEC plays a fundamental role in collecting and disseminating information, coordinating national response activities and initiating cleanup operations. ${ }^{103}$ In the Arctic, the MOSPA establishes a regional mechanism for furthering cooperation on the response to accidental offshore oil pollution in the Arctic. ${ }^{104}$ In the context of the Helsinki Convention, HELCOM cooperates closely with other relevant international global and regional bodies, such as the IMO and the Bonn Agreement working group, to ensure the effective implementation of measures to prevent and respond to accidental oil pollution in the Baltic Sea. ${ }^{105}$

Regional institutions serve as fora for the exchange of information among their contracting parties and further consultations on scientific, technological and legal developments. ${ }^{106}$ In that respect, scientific committees under regional sea agreements have played a key role by increasing awareness of the environmental status of marine regions and evaluating the impact of offshore energy activities. Their input has been greatly influential in devising region-specific standards to address local challenges. For instance, the relevant decisions and resolutions adopted by the OSPAR Commission are heavily influenced by the increasing scientific awareness regarding the impacts of ongoing offshore energy activities in the North-East Atlantic. ${ }^{107}$ In that regard, the Quality Status Reports by the OSPAR Commission offer valuable scientific input for standard-setting. ${ }^{108}$ Concerning offshore oil and gas activities, the Arctic Council has played a key role in conducting scientific assessments of their environmental effects and in producing non-binding instruments on the prevention and control of pollution associated with them. As far as scientific research is concerned, the Arctic Council's various working groups have accomplished significant results in establishing

\footnotetext{
100 See discussion below, section 3.2.

${ }^{101}$ Harrison (2017) supra n. $70,9$.

102 Boczek (1984) supra n. 13, 53.

${ }^{103}$ Mediterranean Emergency Protocol, articles 4, 7, 8, 10, 11, 12.

${ }^{104}$ MOSPA, articles 8, 12 and 13.

${ }^{105}$ Helsinki Convention, Annex VII, Regulation 10.4.

106 Okidi (1990) supra n. 50, 179-180.

107 Article 6 and Annex IV of the OSPAR dictates that measures and programmes adopted by the commission shall be based on relevant monitoring of the environmental status of the region.

${ }^{108}$ Hey (2002) 'The International Regime for the Protection of the North Sea: From Functional Approaches to a More Integrated Approach', International Journal of Marine and Coastal Law, 346.
} 
environmental baselines. ${ }^{109}$ Based on the scientific findings, working groups also make policy recommendations to the Senior Arctic Officials and ministers. ${ }^{110}$ These examples illustrate that the institutional framework of regional arrangements enables an ongoing fruitful discussion about scientific evidence and regulatory tools to address the environmental impacts of both traditional oil and gas activities and renewables at sea. At the same time, the scientific findings specify the required standard of diligence by building a common understanding among the parties of these regional agreements on what is necessary to prevent and reduce adverse environmental impacts of offshore energy production. ${ }^{111}$

\section{Regional rules without borders? The potential "extraterritorial" relevance of regional environmental rules and standards for offshore energy production}

These normative developments across various marine regions can operate as best practices and inspire the adoption of offshore energy-related rules in other areas. ${ }^{112}$ However, the crux of the matter remains whether regionally developed rules and standards can also have an extraterritorial normative impact, in the sense of functioning as benchmarks for assessing the conduct of States in other regions. That would be particularly important for coastal States in many marine areas, such as the Wider Caribbean, the Black Sea, and East Asian Seas, where specific rules on the regulation of offshore energy activities are yet to be developed.

3.1. Regional normative developments as international rules, standards and recommended practices and procedures for article 208(3) UNCLOS

Given that the vast majority of rules and standards on offshore energy activities have been promulgated at the regional level, it is likely that such norms become legally relevant for the implementation of article 208 of UNCLOS. In particular, this provision requires the subsequent articulation of more specific rules and standards ${ }^{113}$ for the implementation of the obligation to prevent pollution from seabed activities. The question is whether rules and standards developed under regional agreements can be generally applicable or "international" in the meaning of article 208(3) of UNCLOS, which explicitly requires that domestic measures must be "no less effective" than such international rules and standards. ${ }^{114}$ Relevantly, the rule of reference under article 208(3) does not refer to global rules ${ }^{115}$ but instead sets "international" rules, standards and recommended practices and procedures as the minimum standard with which domestic regulation must abide. In that respect, it is also noteworthy that UNCLOS

109 E Kirk, and R Miller (2018) 'Offshore Oil \& Gas Installations in the Arctic: Responding to Uncertainty through Science and Law’, Arctic Yearbook, 263.

110 Ibid.

${ }^{111}$ Mayrand (2015) supra n. 94, 288.

112 J Rochette, M Wemaere, L Chabason, and S Callet (2014) 'Seeing beyond the Horizon for Deepwater Oil and Gas: Strengthening the International Regulation of Offshore Exploration and Exploitation', IDDRI Study 01/14, 28.

${ }^{113}$ R Barnes, 'The Continuing Vitality of UNCLOS' in J Barrett, and R Barnes (eds) Law of the Sea: UNCLOS as a Living Treaty (British Institute of International and Comparative Law, 2016).

${ }^{114}$ The relevant provision of the ISNT/Part III referred to the "generally accepted international rules, standards, recommended practices and procedures” (emphasis added), see M Nordquist, N Grandy, S Rosenne, and A Yankov (eds) United Nations Convention on the Law of the Sea 1982: A Commentary, Volume IV (Brill/Martinus Nijhoff, 1991) 142.

${ }^{115}$ See, in comparison, article 210(6) UNCLOS. 
explicitly obliges States to consider recommended regional standards in adopting domestic measures under its article $119 .{ }^{116}$ Thus, in principle, UNCLOS does not exclude the potential of regional norms to provide the minimum standard for domestic regulations. However international rules and standards are required to be generally accepted. ${ }^{117}$ In other words, these rules and standards only become international in the meaning of article 208(3) of UNCLOS by way of their widespread acceptance by, at the least, a representative number of specially affected States. ${ }^{118}$ Arguably, common rules found across different regional arrangements could be considered to be generally accepted as long as there is consistent and widespread State practice. ${ }^{119}$ Regional normative developments can play an influential role in catalysing consistent State practice concerning pollution prevention from seabed activities and, in that way, fill the gaps in the implementation of UNCLOS in the offshore energy sector. ${ }^{120}$

The arguments against accepting that regional norms can be considered international under the rule of reference ${ }^{121}$ appear to be based on the premise that a regional initiative by a few States cannot justify such normative output becoming binding upon third States. Indeed, the practice of a few States cannot create globally applicable international law. However, from a strictly legal point of view, the rule of reference in article 208(3) of UNCLOS does not question the relevance of the consent of States to be bound by international rules. The provision does not make international rules and standards legally binding upon States, which have not adhered to them. Instead, it creates a duty to adopt domestic rules which are at least as equivalently effective as international rules and standards. ${ }^{122}$ In the words of Barnes, the rule of reference requires "what might be called parallelism: the adoption of equivalent rules". ${ }^{123}$ States have to adopt equivalent rules and standards and not simply integrate these international standards. Therefore, even if it is accepted that regionally developed international rules and standards qualify as international standards for article 208(3) of UNCLOS, these standards do not become strictly speaking legally binding upon third States. ${ }^{124}$ Nonetheless, they still have legal effects on third States, and they are in that sense legally relevant since they function as benchmarks for assessing their conduct in

${ }^{116}$ UNCLOS, article 119(1)(a) reads as follows: "In determining the allowable catch and establishing other conservation measures for the living resources in the high seas, States shall (a) take measures ... taking into account ... any generally recommended international minimum standards, whether subregional, regional or global".

117 See, for instance, South China Sea award, paras 1081-1083, which relied on the fact that the COLREGS comprises one of the most widely adopted multilateral conventions in force to conclude that its regulations are generally accepted for the purpose of the rule of reference under article 94 of UNCLOS. In that way it seems to have relied on the number of ratifications (156 Contracting Parties) of the convention by the representative States, given that they represent 98 percent of world shipping tonnage.

118 B Oxman (2001) 'The Duty to Respect Generally Accepted International Standards', New York University Journal of International Law and Policy, 133

${ }^{119}$ Harrison (2017) supra n. 70, 225, ILA (2000) Committee on Coastal State Jurisdiction Relating to Marine Pollution, Final Report, 160, A Boyle (2005) 'Further Development of the Law of the Sea Convention: Mechanisms for Change', International Law and Comparative Law Quarterly, 569.

${ }^{120}$ Redgwell (2014) supra n. 3, 611-612.

${ }^{121}$ ILA (2000) supra n. 119, 160.

${ }^{122}$ A Proelss (ed) United Nations Convention on the Law of the Sea: A Commentary (Hart/ Nomos, 2017) 1397.

${ }^{123}$ Barnes (2016) supra n. 113, 20.

${ }^{124}$ Contra Harrison (2017) supra n. 70, 225. 
complying with the duty to protect and preserve the marine environment in the context of seabed activities.

That argument does not necessarily contradict the pronouncement of the arbitral tribunal in the South China Sea Arbitration concerning another rule of reference under UNCLOS. ${ }^{125}$ According to the tribunal, article 94 of UNCLOS incorporates the regulations of COLREGS as generally accepted. For that reason, it upheld that COLREGS was applicable in the dispute, even though the Philippines had not been a party to it before 2013. ${ }^{126}$ However, that incorporation of COLREGS by reference takes place because article 94 of UNCLOS explicitly requires States "to conform to generally accepted international regulations, procedures and practices and take any steps which may be necessary to secure their observation". By contrast, article 208(3) of UNCLOS only requires that domestic regulation is at least as effective as the international rules, standards, and recommended practices and procedures.

Moreover, the fact that these international rules and standards set an international minimum standard against which domestic rules must be evaluated does not breach the pacta tertiis rule. That is because the adherence of States to UNCLOS is an expression of their consent to be bound by such an evolving standard of due diligence. ${ }^{127}$ This observation raises a question regarding the limits of the expressed consent of States adhering to UNCLOS. The suggestion that parties to UNCLOS are bound by an evolving minimum standard is not far-fetched if one considers that due diligence is an inherently flexible standard. UNCLOS does not prescribe the content of domestic measures and regulations for offshore activities. States still enjoy discretion in implementing their duty to formulate domestic regulation, ${ }^{128}$ which must merely be equivalent to international standards. The provision seems to focus on the result of those measures and not their content. Moreover, in choosing the equivalent measures, States are allowed to take into account regional specificities and their economic and technical capacity. Therefore, regional rules and standards, insofar as they are generally accepted, can indicate how States can implement their duty to prevent pollution from offshore energy activities. Such a reading of the provision could resonate better with States in regions that have traditionally underlined the significance of State consent and have shown a specific "allergy" to undertaking new binding commitments.

3.2. Regional normative developments as subsequent agreements/practice for the interpretation of UNCLOS

In addition, insofar as these rules and standards reflect a pattern in regional treaties, they hold considerable potential to guide the interpretation and implementation of the relevant duties under UNCLOS. ${ }^{129}$ In particular, the rules of treaty interpretation call on the interpreter of UNCLOS to read its provisions, among others, in the normative context of other environmental agreements. However, that does not necessarily mean that treaty interpretation rules enable its interpreter to constantly engage in a process of

\footnotetext{
${ }^{125}$ See South China Sea Arbitration, paras 1081-1083.

${ }^{126}$ Ibid, para 1082.

${ }^{127}$ ILA (2000) supra n. 119, 57.

${ }^{128}$ UNCLOS, article 208(1).

${ }^{129}$ Boyle (2005) supra n. 119, 569, Harrison (2017) supra n. 70, 225.
} 
updating the Convention's provisions in the light of each new treaty on the protection of the marine environment. ${ }^{130}$ There are limits to this process. ${ }^{131}$ In the case of major multilateral treaties, such as UNCLOS, developing consensus among the parties for an agreement on their interpretation is a difficult task. ${ }^{132}$ Regional sea agreements often refer to UNCLOS in their preamble ${ }^{133}$ and they have been a means of implementing the provisions of Part XII of UNCLOS even before the Convention entered into force in 1994. ${ }^{134}$ Although that does not necessarily mean that their parties intended them to serve as interpretive agreements of UNCLOS, they could be considered as a form of subsequent practice of some of the parties to UNCLOS. The drafting history of article 31(3)(b) of the VCLT can assist in clarifying the requirements for regional agreements to serve as a means of interpretation. Specifically, the wording of the provision changed from referring to the agreement "of all parties" to the agreement "of the parties". That change might indicate that it is not necessary for all parties to a multilateral agreement to actively engage in a subsequent practice regarding its implementation. ${ }^{135}$

If we consider the rules under each regional sea agreement individually, these rules cannot provide sufficient evidence of widespread State practice regarding the interpretation of prevention obligations under global treaties. One needs to be careful not to impose through interpretation rules and standards that are well developed and supported in one region on states beyond that region, without their consent. ${ }^{136}$ As stressed by the ITLOS in the MOX Plant case, one needs to duly consider, inter alia, differences in the respective contexts, objects and purposes, subsequent practice of the parties and travaux préparatoires even when interpreting similar provisions of different treaties. ${ }^{137}$

Nonetheless, convergence among multiple regional agreements may indicate representative State practice, which can inform the interpretation of the environmental obligations under UNCLOS. ${ }^{138}$ Parallel consistent conduct by its parties across different regions may suffice if it articulates a sufficiently common understanding regarding the interpretation of the treaty. ${ }^{139}$ In the context of the dynamic treaty regime established by UNCLOS, its general environmental obligations can gain normative content "through regime interaction fueled by subsequent practice". ${ }^{140}$ Using subsequent practice as a means of evolutionary interpretation of UNCLOS safeguards

\footnotetext{
${ }^{130}$ Boyle (2005) supra n. 119, 568.

${ }^{131}$ J Harrison (2019) 'The Protection of Species, Ecosystems and Biodiversity under UNCLOS in Light of the South China Sea Arbitration: An Emergent Duty of Marine Ecosystem Restoration?', Edinburgh School of Law Research Paper No 2019/20, 9.

${ }^{132}$ S D Murphy, 'The Relevance of Subsequent Agreement and Subsequent Practice for the Interpretation of Treaties', in G Nolte (ed) Treaties and Subsequent Practice (Oxford University Press, 2013) 85.

${ }^{133}$ For instance, see OSPAR, preamble, 1995 Barcelona Convention, preamble.

${ }^{134}$ Boyle (2005) supra n. 119, 575-576.

135 S Raffeiner (2016) supra n. 99, 1052.

136 J Harrison (2019) supra n. 131, 9.

${ }^{137}$ See ITLOS, MOX Plant Case, Provisional Measures Order, 3 December 2001, para 5.1.

${ }^{138}$ Harrison (2017) supra n. 70, 225.

139 ILC Draft conclusions on subsequent agreements and subsequent practice in relation to the interpretation of treaties (2018), Yearbook of the International Law Commission, vol II, Part Two. commentary on draft conclusion 6.

${ }^{140}$ I Buga, Modification of Treaties by Subsequent Practice (Oxford University Press, 2018) 337.
} 
its resilience. ${ }^{141}$ In that respect, the more elaborate provisions of some regional agreements could specify the standard of care in the interpretation of "all the appropriate measures" that States must take to prevent pollution from offshore energy production activities. In other words, they can serve as benchmarks by which to assess the reasonableness of domestic measures implementing the relevant duty to protect the marine environment under UNCLOS.

Since only a few regional agreements contain specific rules on the prevention of pollution from offshore energy activities, recourse should be had to the relevant State conduct in regulating these activities at the domestic level. Such a cautious approach appears to be advocated by the ILC in its 2018 draft conclusions on subsequent agreements and practice for treaty interpretation, which underlined that agreements or practice between less than all parties to a treaty regarding the interpretation or the application of that treaty are not to be considered as an authentic means of interpretation under article 31(3)(a) and (b) of the VCLT. Instead, in the ILC's view, such practice should be received as a form of practice under article 32 of the VCLT. ${ }^{142}$ Therefore, even if regional agreements do not meet the requirement of concordant, common and consistent State practice in the application of UNCLOS, ${ }^{143}$ they could still be considered as "other subsequent practice" under article 32 of the VCLT. In particular, subsequent practice in the application of a treaty, which establishes the agreement of only one or more parties to an agreement may function as supplementary means of interpretation. ${ }^{144}$ In light of the above conclusions of the ILC, even when regional agreements do not represent sufficient State practice for the interpretation and implementation of UNCLOS, their "extraterritorial" normative impact is not diminished. ${ }^{145}$ They are still legally relevant in clarifying the content of the duty to protect and preserve the marine environment in the context of offshore energy production activities under UNCLOS. ${ }^{146}$

However, the reasoning of the arbitral tribunal in the South China Sea Arbitration seems to indirectly question such a strict interpretation of article 31(3)(a) and (b) of the VCLT. In particular, the arbitral tribunal relied on the "nearly universal adherence" of states to CITES, even though it is not binding on all parties to UNCLOS, to justify using it as the normative context for the interpretation of the Convention. ${ }^{147}$ That widespread participation in CITES was sufficient proof that it belongs to "the general corpus of international law that informs the content of article 192 and 194(5)" of UNCLOS. ${ }^{148}$ The reasoning of the tribunal suggests some flexibility in identifying the rules, which

${ }^{141}$ G Nolte (2020) 'Introductory Note to the Special Issue of ICLR on the Outcome of the ILC Work on Subsequent Agreements and Subsequent Practice in Relation to the Interpretation of Treaties', International Community Law Review, 6.

${ }^{142}$ ILC Draft Conclusions (2018) supra n. 139.

${ }^{143} \mathrm{Ibid}$, with reference to the WTO Appellate Body Report, Japan - Alcoholic Beverages II, section E, para 16.

${ }^{144}$ Ibid, commentary to draft conclusion 4.

${ }^{145}$ M Fitzmaurice (2020) 'Subsequent Agreements and Subsequent Practice: Some Reflections on the International Law Commission's Draft Conclusions', International Community Law Review, 19.

${ }^{146}$ N Matz-Lück, and E Van Doorn (2017) 'Due Diligence Obligations and the Protection of the Marine Environment', L'Observateur Des Nations Unies, 169-187.

${ }^{147}$ South China Sea Arbitration, para 942.

${ }^{148}$ Ibid. 
can inform the interpretation of the environmental duties under UNCLOS. ${ }^{149}$ In light of that argument, subsequent agreements or practice for the interpretation of UNCLOS do not need to be attributed to all the parties of the Convention, but nearly all of them. In that case, participation from a cross-section of States from around the world can be significant for accepting the relevance of subsequent practice or agreements in the interpretation of UNCLOS. ${ }^{150}$ Similarly, Boyle has argued that an agreement lacking the support of all parties to UNCLOS may still provide interpretative guidance. However, its "persuasive force" as a basis for the interpretation of UNCLOS "will be necessarily weaker the fewer parties there are". ${ }^{151}$

Concluding Remarks

Building upon the general environmental obligations under UNCLOS, regional arrangements have considerably contributed to the development of environmental rules and standards directly applicable to offshore energy production activities. In that fashion, they shape the normative content and guide the implementation of the duty to protect the marine environment in relation to such activities at the regional level. For instance, they have attached binding force to some principles and concepts which until the Rio Conference in 1992, if at all, merely existed as non-binding recommendations. They oblige their parties to adopt measures not only to prevent and reduce specific "traditional" sources of marine pollution but also - extremely importantly in respect of marine renewables - to protect and restore marine biodiversity, emphasising a more holistic, ecosystem-based and precautionary approach to the problem of marine environment degradation by human activities

Significantly, regional instruments also contain substantive environmental rules on offshore oil and gas activities, which can give normatively concrete content to the duty to "take all necessary measures" and specify the "best practicable means" to be used. ${ }^{152}$ However, it is remarkable that, at present, there are no specific regional rules on the environmental regulation of marine renewables. Instead, the potential risks from marine renewable energy generation are regulated - often incidentally - under general environmental obligations relating to nature conservation. That being said, the environmental externalities of marine renewables are addressed in several non-binding instruments by treaty bodies to regional agreements. These guidelines could offer valuable interpretative guidance on the implementation of environmental obligations, considering the specificities of marine renewable energy production activities.

Despite their structural differences, the examined regional arrangements vividly illustrate how regional cooperation can be dynamic and responsive to changes as well as capable of meeting specific regional needs and formulating region-specific approaches through "secondary" normative developments. Although most of these secondary instruments are not binding, they are legally relevant in updating the normative content of the respective treaty rules. Apart from their contextual significance in the process of interpretation under article 32 of the VCLT, their legal

\footnotetext{
${ }^{149}$ Harrison (2019) supra n. 131, 8.

${ }^{150} \mathrm{Ibid}, 9$.

${ }^{151}$ Boyle (2005) supra n. 70, 571.

${ }^{152}$ See article 194 of UNCLOS.
} 
relevance lies in their capacity to stimulate consistent State practice. In addition, scientific findings by treaty bodies can contribute to creating a shared understanding among the parties regarding the risks from offshore energy production and the necessary measures for their mitigation. Overall, this less formalistic approach of standard setting appears to have played a catalytic role in substantiating the due diligence obligation of prevention of pollution from offshore energy activities in different marine regions. Noticeably, that flexible approach has also enabled States to involve relevant stakeholders in the energy sector, be that indigenous populations, NGOs, or the private energy industry in the law-making and the implementation of environmental standards.

Regional rules and standards have a considerable capacity in acting as transposable environmental standards in other marine regions both at the law-making and the implementation phases. However, the legal borrowing of rules and standards from different regions must be conducted with caution, considering the regional specificities and needs of the receiving body of law. Instead of merely "transplanting rules, States can draw upon best practices followed in normatively advanced regions and adapt them to fit their legal framework. In addition, common regional rules and standards on the environmental regulation of offshore energy production found across a cross-section of representative marine regions can, under certain conditions, serve as international minimum standards under article 208(3) of UNCLOS. Take, for example, the requirement of prior authorisation, the application of BAT and BEP and the limits regarding operational discharges, which are commonly found as rules applicable to offshore oil and gas activities under several relevant regional sea agreements. Even if those rules are not directly binding on States in different marine regions, they contribute towards the development of transposable best practices. Additionally, insofar as these regional rules catalyse consistent, widespread State practice, they might be used as a means for the interpretation of UNCLOS under article 31(3) (b) of the VCLT. Therefore, the importance of regional initiatives should not be overlooked, because they have served as an outstanding "legal laboratory" for rules and standards relating to offshore energy production. 